\title{
Rancang Bangun Vehicle Routing Problem Menggunakan Algoritma Tabu Search
}

\author{
Sulistiono dan Noor Saif Muhammad Mussafi \\ Program Studi Matematika Fakultas Sains dan Teknologi, UIN Sunan Kalijaga, Jl. Marsda Adisucipto \\ No. 1 Yogyakarta, Indonesia \\ Korespondensi; Noor Saif Muhammad Mussafi; Email: noor.saif@uin-suka.ac.id
}

\begin{abstract}
Abstrak
Pendistribusian produk berperan penting dalam dunia industri. Salah satu usaha yang dapat dilakukan perusahaan untuk mengoptimalkan pendistribusian produk adalah meminimalkan biaya tranportasi melalui penentuan rute optimal kendaraan yang disebut dengan VRP (Vehicle Routing Problem). Tujuan dari VRP adalah menentukan rute optimal yaitu rute dengan jarak minimum untuk mendistribusikan produk kepada konsumen. Salah satu variasi VRP adalah Capacitated Vehicle Routing Problem (CVRP), yaitu VRP dengan kendala kapasitas kendaraan. Kasus CVRP tersebut dapat diselesaikan dengan menggunakan Algoritma Tabu Search. Cara kerja Algoritma Tabu Search dimulai dengan penentuan initial solution menggunakan Nearest Neighbor, evaluasi move menggunakan metode 2-Opt, Relocated, dan Exchange, update Tabu List, kemudian apabila kriteria pemberhentian terpenuhi maka proses Algoritma Tabu Search berhenti jika tidak, maka kembali pada evaluasi move. Proses perhitungan Algoritma Tabu Search dilakukan secara manual dan rancang bangun menggunakan MATLAB pada PT Sinergi Bio Natural. Berdasarkan proses perhitungan manual dan rancang bangun diperoleh dua solusi optimal yaitu rute dengan jarak terpendek dengan total jarak optimal sebesar $101,1 \mathrm{~km}$.
\end{abstract}

Kata Kunci: Vehicle Routing Problem (VRP); Capacitated Vehicle Routing Problem (CVRP); Algoritma Tabu Search

\begin{abstract}
Distribution of the product has an important role in the industrial world. One attempt to do company to optimize the distribution of the products is to minimize transport costs through optimal vehicle routing called VRP (Vehicle Routing Problem). The objective of the VRP is determining the optimal route is the route with the minimum distance for distributing products to consumers. One variation of the VRP is Capacitated Vehicle Routing Problem (CVRP), the VRP with vehicle capacity constraints. The CVRP cases can be solved by using Tabu Search Algorithm. How it works Algorithm Tabu Search starts with the determination of the initial solution using the Nearest Neighbor, evaluating the move using 2-Opt, Relocated, and Exchange, updates Tabu List, then when the criteria for termination are met then the algorithm Tabu Search stop if not, then go back to the evaluation of the move, Tabu Search Algorithm calculation process is done manually and design using MATLAB PT Synergy Bio Natural. Based on the manual calculation process and design the optimal solution is obtained by two routes with the shortest distance to the optimal total distance of $101.1 \mathrm{~km}$.
\end{abstract}

Keywords: Vehicle Routing Problem (VRP); Capacitated Vehicle Routing Problem (CVRP); Tabu Search Algoritm

\section{Pendahuluan}

Pada dunia industri, logistik memiliki peranan penting dalam meningkatkan kinerja suatu perusahaan. Kemampuan perusahaan untuk mengelola logistik secara efektif dan efisien dapat mempengaruhi biaya dan tingkat pelayanan terhadap konsumen sehingga dapat bersaing dengan perusahaan sejenis lainnya. Salah satu usaha yang dapat dilakukan perusahaan untuk mengoptimalkan pendistribusian produk adalah meminimalkan biaya tranportasi melalui penentuan rute optimal kendaraan yang disebut Vehicle Routing Problem (VRP). Kasus VRP merupakan TSP dengan menyertakan kendala satu kendaraan 
dengan kapasitas sehingga digolongkan ke dalam NP-Hard Problem karena secara teori ataupun praktik pada dunia nyata memiliki permasalahan yang sangat banyak dan kompleks sehingga sulit untuk dipecahkan. Kasus NP-Hard dapat diselesaikan menggunakan pendekatan solusi optimal dengan metode heuristik yang memberikan perkiraan solusi [4]. Dibandingkan dengan metode heuristik klasik, metaheuristik menunjukkan pencarian solusi yang lebih teliti.

Algoritma Tabu Search merupakan salah satu metode metaheuristik yang dapat menuntun prosedur pencarian lokal heuristik untuk menjelajahi daerah solusi di luar titik optimal lokal [10]. Algoritma Tabu Search dapat digunakan untuk mencari solusi optimal VRP yaitu rute yang memiliki total jarak tempuh minimum dengan mempertimbangkan kapasitas kendaraan. Langkah Algoritma Tabu Search dimulai dengan penentuan initial solution menggunakan Nearest Neighbor, evaluasi move menggunakan metode 2-Opt, Relocated, dan Exchange, update Tabu List, kemudian apabila kriteria pemberhentian terpenuhi maka proses Algoritma Tabu Search berhenti jika tidak, maka kembali pada evaluasi move. Pembuatan suatu program (rancang bangun) dapat mempercepat proses pencarian solusi optimal pada VRP. Program (rancang bangun) dibuat menggunakan MATLAB yang dimulai dengan membuat source code utama menggunakan m.file kemudian desain tampilan dirancang menggunakan fig-file sehingga diperoleh program dalam bentuk GUI (Graphical User Interface). Program (rancang bangun) Algoritma Tabu Search dapat memudahkan pencarian solusi optimal VRP yang lebih efektif dan efisien pada PT Sinergi Bio Natural.

\section{Landasan Teori}

\section{Teori Graf}

Suatu graf $G$ merupakan pasangan himpunan $(V, E)$ ditulis dengan notasi $G=(V, E)$, dimana $V$ adalah himpunan berhingga dan tak kosong dari simpul (nodes) sedangkan $E$ adalah himpunan sisi (edges) yang menghubungkan sepasang elemen tidak berurutan dari $V$. Elemen dari $V$ dinamakan simpul (nodes), $V=\left\{v_{1}, v_{2}, v_{3}, \cdots, v_{n}\right\}$ dan elemen dari $E$ dinamakan sisi (edge), $E=$ $\left\{e_{1}, e_{2}, e_{3}, \cdots, e_{n}\right\}[11]$.

\section{Graf berarah berbobot}

Graf berarah berbobot adalah graf yang setiap sisinya diberikan orientasi arah dan memiliki bobot. Graf berarah berbobot sering digunakan untuk menggambarkan aliran proses, peta lintas kota dan lainlain. Sehingga, pada graf berarah berbobot tidak memperbolehkan adanya sisi ganda.

\section{Graf Hamilton}

Sebuah lintasan pada graf $G$ yang melalui tiap simpul di dalam graf tersebut tepat satu kali disebut lintasan Hamilton, sedangkan sebuah sirkuit pada Graf $G$ yang melalui tiap simpul tepat satu kali disebut sebagai sirkuit Hamilton [23].

\section{Travelling Salesman Problem (TSP)}

Travelling Salesman Problem (TSP) merupakan suatu permasalahan untuk menemukan rute perjalanan terpendek dari kota asal atau depot kemudian mengunjungi seluruh kota pelanggan yang harus dilalui satu kali dan kembali lagi ke depot. TSP dapat direpresentasikan pada sebuah graf $G=(V, E)$, dimana $V$ adalah simpul (nodes) yang merepresentasikan kota, dan $E$ adalah sisi yang merepresentasikan jalan yang menghubungkan kota tersebut. Secara umum model matematika untuk TSP adalah sebagai berikut [27]:

Diberikan $d_{i j}$ adalah jarak dari kota $i$ ke kota $j\left(d_{i}\right.$, nonnegative $)$ dan $n$ adalah jumlah kota yang akan dilewati. Fungsi tujuannya meminimumkan total jarak tempuh perjalanan salesman. Jika Z adalah fungsi tujuan mak

$$
M \quad Z=\sum_{i=1}^{n} \sum_{j=1}^{n} d_{i} x_{i}
$$


Didefinisikan variabel keputusan:

$x_{i}= \begin{cases}1, & \text { jika salesman melakukan perjalanan dari kota } i \text { ke kota } j \\ 0, & \text { selainnya }\end{cases}$

1. Setiap kota dikunjungi 1 kali

$$
\begin{gathered}
\sum_{i-1}^{n} x_{i}=1, \text { untuk } j=1,2, \ldots, n \\
\sum_{i-1}^{n} x_{i}=1, \text { untuk } i=1,2, \ldots, n \\
x_{i}=0, \text { untuk } i=j
\end{gathered}
$$

2. Variable keputusan $x_{i, j}^{k}$ merupakan bilangan biner

$$
x_{i} \in\{0,1\}, \forall i, j=1,2, \cdots, n
$$

\section{Capacitated Vehicle Routing Problem (CVRP)}

Vehicle Routing Problem (VRP) merupakan bagian dari TSP, artinya VRP merupakan TSP dengan menyertakan kendala satu kendaraan dengan kapasitas [26]. Beberapa komponen beserta karakteristiknya yang terdapat dalam masalah VRP menurut Toth dan Vigo (2002), yaitu depot, jaringan jalan, konsumen, kendaraan dan pengemudi

Capacitated Vehicle Routing Problem (CVRP) merupakan salah satu variasi dari masalah VRP dengan kendala kapasitas kendaraan yang terbatas. CVRP dapat direpresentasikan sebagai suatu graf berarah berbobot (weighted directed graph) $D=(V, A)$ dimana $V=\left\{v_{0}, v_{1}, v_{2}, \cdots, v_{n}\right\}$ adalah himpunan simpul (nodes) dan $A=\left\{\left(v_{i}, v_{j}\right) \mid v_{i}, v_{j} \in V, i \neq j\right\}$ adalah himpunan busur (arcs) yang menghubungkan himpunan simpul (nodes). Simpul $v_{0}$ dinyatakan sebagai depot dan yang lainnya adalah pelanggan. Setiap elemen dari busur (arcS) menyatakan jarak. Sedangkan setiap simpul memiliki permintaan (demand) yang dinotasikan sebagai $q_{i}$, dengan i= $1,2,3, n$. Himpunan $K=\left\{k_{1}, k_{2}, k_{3}, \cdots, k_{n}\right\}$ merupakan kumpulan kendaraan yang homogen. Kapasitas kendaraan yang digunakan dinotasikan dengan $Q$ [3].

Diberikan $d_{i}$ adalah jarak dari simpul $i$ ke simpul $j\left(d_{i}\right.$ merupakan bilangan nonnegative). Jarak diasumsikan semetrik $\left(d_{i}=d_{j}\right)$ dan $\left(d_{i}=d_{j}=0\right)$. Permasalahan tersebut kemudian dapat dibuat menjadi model matematika dengan tujuan meminimumkan total jarak tempuh perjalanan kendaraan: Didefinisikan variabel keputusan

$$
\begin{aligned}
x_{i, j}^{k} & = \begin{cases}1, & \text { jika kendaraan } k \text { mengunjungi simpul } v_{j} \text { setelah simpul } v_{i} \\
0, & \text { selainnya }\end{cases} \\
y_{i}^{k} & = \begin{cases}1, & \text { jika simpul } v_{i} \text { dilayani oleh kendaraan } k \\
0, & \text { selainnya }\end{cases}
\end{aligned}
$$

Keterangan variabel

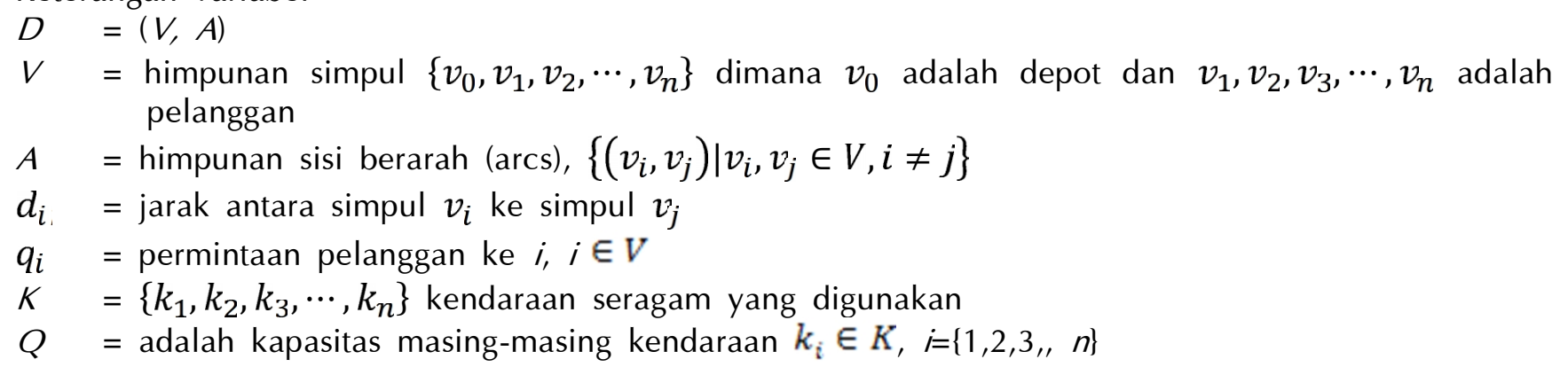


Fungsi tujuannya meminimumkan total jarak tempuh kendaraan. Jika $Z$ adalah fungsi tujuan, maka

$$
M \quad Z=\sum_{k \in K} \sum_{i \in V} \sum_{j \in V} d_{i} x_{i, j}^{k}
$$

Kendala

1. Setiap simpul hanya boleh dikunjungi tepat satu kali oleh 1 kendaraan.

$$
\sum_{k \in K} \sum_{j \in N} x_{i, j}^{k}, \forall i \in V
$$

2. Kendaraan yang telah mengunjungi simpul $i$, kendaraan $k$ harus meninggalkan simpul tersebut menuju simpul lain.

$$
\sum_{j \in V} x_{i, j}^{k}-\sum_{j \in V} x_{j, i}^{k}=0, \forall i \in V, \forall k \in K
$$

3. Total jumlah permintaan pelanggan dalam satu rute tidak melebihi kapasitas kendaraan.

$$
\sum_{i \in V} q_{i} \sum_{j, i \in V, j \neq i} x_{x i j}^{k} \leq Q, \forall k \in K
$$

4. Setiap rute perjalanan kendaraan berawal dari depot

$$
\sum_{j \in V} x_{0, j}^{k}=1, \forall k \in K
$$

5. Setiap rute perjalanan kendaraan berakhir di depot

$$
\sum_{j \in V} x_{j, 0}^{k}=1, \quad \forall k \in K
$$

6. Batasan ini memastikan bahwa tidak terdapat subrute pada setiap rute yang terbentuk.

$$
\begin{gathered}
x_{i, j}^{k}=1 \Rightarrow y_{i^{-}} q_{j}=y_{j}, \quad \forall i, j \in V, k \in K \\
y_{0}=Q_{1} \quad 0 \quad y_{i} \quad \forall i \in V
\end{gathered}
$$

7. Variable keputusan $x_{i, j}^{k}$ merupakan bilangan biner.

$$
x_{i, j}^{k} \in\{0,1\}, \forall i, j \in V, k \in K
$$

Variabel keputusan hanya akan terdefinisi jika jumlah permintaan simpul $v_{i}$ dan simpul $v_{j}$ tidak melebihi kapasitas kendaraan. Apabila kapasitas kendaraan tidak memadahi untuk pelanggan berikutnya maka kendaraan harus mengisi muatan di depot sehingga akan terbentuk rute baru.

\section{Algoritma Tabu Search}

Algoritma Tabu Search memiliki Lima elemen utama yang digunakan untuk menyelesaikan VRP yaitu: 1. Representasi Solusi

Representasi solusi yang digunakan Algoritma Tabu Search adalah suatu urutan titik-titik (nodes), dimana tiap titik (node) hanya terlihat sekali dalam urutan. Titik (node) tersebut merepresentasikan depot dan pelanggan. 


\section{Pembentukan Solusi Awal (Initial Solution)}

Solusi awal dibentuk menggunakan metode random atau metode heuristik yang akan diperbaiki pada iterasi berikutnya.

3. Solusi Neighborhood

Solusi Neighborhood merupakan solusi alternatif yang diperoleh dengan melakukan perpindahan node (move). Setiap perpindahan node (move) akan menghasilkan satu solusi Neighborhood.

4. Tabu List

Tabu list berisi atribut move yang telah ditemukan sebelumnya. Ukuran Tabu List akan bertambah seiring meningkatnya ukuran masalah. Ukuran Tabu List yang terlalu panjang tidak akan menghasilkan kualitas solusi yang baik karena dapat menyebabkan terlalu banyak perpindahan node (move) yang dilarang (Glover dan Kochenberger, 2003).

5. Kriteria Aspirasi

Kriteria aspirasi adalah suatu metode untuk membatalkan status tabu (Glover dan Kochenberger, 2003).

6. Kriteria Pemberhentian.

Kriteria pemberhentian (termination criteria) yang dipakai yaitu setelah semua iterasi yang telah ditentukan terpenuhi.

\section{Metode Penelitian}

Data yang digunakan dalam penelitian ini adalah data permintaan pelanggan, jarak antar pelanggan, jarak depot ke pelanggan dan kapasitas kendaraan PT Sinergi Bio Natural sebagai salah satu produsen Bioseptik di daerah Yogyakarta dan sekitarnya. Diperoleh data dengan pelanggan sebanyak 16, kapasitas maksimal kendaraan yaitu 300 liter, serta jarak antar pelanggan. Kemudian dapat dilakukan proses perhitungan dengan langkah-langkah sebagai berikut:

1. Pembentukan Solusi Awal (Initial Solution)

Solusi Awal pada Algoritma Tabu Search diperoleh menggunakan metode Nearest Neighbor.

2. Menentukan solusi Neighborhood dengan evaluasi move

Pada Algoritma Tabu Search, solusi Neighborhood merupakan solusi alternatif yang diperoleh dengan melakukan perpindahan node (move). Setiap perpindahan node (move) akan menghasilkan satu solusi Neighborhood. Perpindahan node (move) dilakukan menggunakan metode heuristik yaitu 2Opt, Relocated, dan Exchange.

3. Analisa solusi optimal VRP menggunakan Algoritma Tabu Search.

Solusi Optimal diperoleh menggunakan Algoritma Tabu Search setelah semua iterasi dipenuhi.

4. Pembuatan program (rancang bangun) menggunakan MATLAB.

Rancang bangun dibuat menggunakan software MATLAB 8.1 yang dijalankan menggunakan laptop dengan processor Intel Core i3 dan RAM 1024 MB.

5. Interpretasi solusi VRP pada graf.

Solusi optimal yang didapatkan menggunakan Algoritma Tabu Search direpresentasikan pada graf di peta Yogyakarta.

\section{Hasil dan Pembahasan}

\section{Penerapan Algoritma Tabu Search secara Manual}

Penerapan Algoritma Tabu Search pada kasus pendistribusian Bioseptik menggunakan data permintaan (Tabel 1) dan jarak (Tabel 2) sebagai berikut: 
Tabel 1 Data permintaan pelanggan Bioseptik.

\begin{tabular}{crcr}
\hline Pelanggan & Permintaan & Pelanggan & Permintaan \\
\hline 1 & 50 liter & 10 & 10 liter \\
2 & 70 liter & 11 & 35 liter \\
3 & 300 liter & 12 & 55 liter \\
4 & 40 liter & 13 & 40 liter \\
5 & 20 liter & 14 & 20 liter \\
6 & 5 liter & 15 & 25 liter \\
7 & 10 liter & 16 & 50 liter \\
8 & \multicolumn{3}{c}{ liter } \\
\hline Sumber: Laporan Pengiriman Bioseptik PT Sinergi Bio Natural
\end{tabular}

Tabel 2 Jarak depot ke pelanggan dan antar pelanggan dalam satuan kilometre.

\begin{tabular}{|c|c|c|c|c|c|c|c|c|c|c|c|c|c|c|c|c|}
\hline Pelanggan & 1 & 2 & 3 & 4 & 5 & 6 & 7 & 8 & 9 & 10 & 11 & 12 & 13 & 14 & 15 & 16 \\
\hline 1 & 0 & 8,9 & 16.2 & 4,6 & 19,4 & 14,2 & 10,7 & 6,3 & 7 & 2,4 & 17,2 & 8,7 & 0,7 & 1,4 & 6,9 & 8,3 \\
\hline 2 & & 0 & 8,9 & 6 & 15,9 & 9,6 & 5,1 & 3,3 & 4 & 9,1 & 8,8 & 6,2 & 8,5 & 8,5 & 9,0 & 1 \\
\hline 3 & & & 0 & 13,7 & 12,6 & 12,3 & 7 & 11,6 & 10,3 & 17,7 & 3,2 & 13,4 & 17,1 & 16,1 & 16,7 & 8,6 \\
\hline 4 & & & & 0 & 25,8 & 9,5 & 11,1 & 3,2 & 2,4 & 6,6 & 12,2 & 9,2 & 5 & 3,9 & 4,6 & 6,7 \\
\hline 5 & & & & & 0 & 24,8 & 10,4 & 16,9 & 21,2 & 19,1 & 15,9 & 14,5 & 19,8 & 21,5 & 27,6 & 14,3 \\
\hline 6 & & & & & & 0 & 18,5 & 10,8 & 8,5 & 15,1 & 10,4 & 13,9 & 14,2 & 13,4 & 8,7 & 10,6 \\
\hline 7 & & & & & & & 0 & 6,6 & 9,2 & 11 & 10,4 & 7,5 & 10,9 & 11,4 & 15 & 4 \\
\hline 8 & & & & & & & & 0 & 4 & 7,9 & 10,9 & 5,2 & 7,4 & 7,1 & 8,9 & 2 \\
\hline 9 & & & & & & & & & 0 & 7,8 & 9,8 & 8,8 & 6,6 & 6,1 & 5 & 5,6 \\
\hline 10 & & & & & & & & & & 0 & 20,1 & 6 & 2,8 & 3,8 & 9,4 & 8,6 \\
\hline 11 & & & & & & & & & & & 0 & 14,7 & 16,9 & 16,2 & 16,4 & 9,1 \\
\hline 12 & & & & & & & & & & & & 0 & 7,4 & 8,3 & 13,5 & 6,1 \\
\hline 13 & & & & & & & & & & & & & 0 & 1,6 & 7,6 & 8,1 \\
\hline 14 & & & & & & & & & & & & & & 0 & 7 & 7,4 \\
\hline 15 & & & & & & & & & & & & & & & 0 & 10,7 \\
\hline 16 & & & & & & & & & & & & & & & & 0 \\
\hline
\end{tabular}

Kemudian proses perhitungan Algoritma Tabu Search secara manual dilakukan dengan langkahlangkah sebagai berikut:

1. Langkah pertama yang dilakukan adalah menentukan solusi awal sebagai solusi optimum pada iterasi ke-0 dengan metode Nearest Diperoleh solusi TSP Awal Solusi awal 1-13-14-10-12-8-16-29-4-15-6-11-3-7-5-1. Solusi TSP awal yang diperoleh kemudian dibatasi berdasarkan kapasitas kendaraan dan permintaan pelanggan. Jika kapasitas kendaraan sudah tidak dapat memenuhi permintaan pelanggan berikutnya maka kendaraan kembali lagi ke depot untuk mengisi muatan dan melanjutkan perjalanan dengan rute yang baru sampai semua node dikunjungi. Total permintaan tiap rute merupakan total permintaan tiap pelanggan yang sudah dilewati oleh kendaraan pada tiap rute. Sedangkan total jarak tiap rute merupakan jumlah jarak yang dilalui kendaraan saat mengantarkan pesanan kepada pelanggan dalam tiap rute. Diperoleh Rute VRP awal pada Tabel 3:

Tabel 3 Solusi awal VRP menggunakan metode Nearest Neighbor.

\begin{tabular}{cllr}
\hline Rute & Solusi awal VRP & Permintaan & Jarak \\
\hline 1 & $1-13-14-10-12-8-16-2-9-1$ & 240 liter & $31,3 \mathrm{~km}$ \\
2 & $1-4-1$ & 300 liter & $9,2 \mathrm{~km}$ \\
3 & $1-15-6-11-3-7-5-1$ & 240 liter & $66 \mathrm{~km}$ \\
\hline \multicolumn{2}{r}{ Total jarak tempuh kendaraan } & $106,5 \mathrm{~km}$ \\
\hline
\end{tabular}


2. Langkah ke-2 yaitu menentukan iterasi selanjutnya dan mencari solusi Neighborhood TSP. Solusi Neighborhood TSP dan node yang ditukar dihasilkan menggunakan tiga metode Relocated, Exchange, atau 2-Opt yang dipilih secara random sedemikian sehingga diperoleh solusi Neighborhood terbaik. Berikut merupakan salah satu solusi Neighborhood TSP yang diperoleh menggunakan metode Exchange (Perhatikan Tabel 4)

Tabel 4 Solusi Neighborhood TSP.

\begin{tabular}{lrrr}
\hline Metode & \multicolumn{2}{c}{ Move } & Solusi Neighborhood TSP \\
\hline Exchange & 9 & 2 & $1-13-14-10-12-8-16-9-2-4-15-6-11-3-7-5-1$ \\
\hline
\end{tabular}

Setelah diperoleh solusi Neighborhood TSP, maka setiap solusi-solusi tersebut ditransformasi menjadi solusi Neighborhood VRP. Pembagian jumlah rute solusi Neighborhood VRP berdasarkan permintaan pelanggan pada urutan kunjungan yang diperoleh dari solusi Neighborhood TSP. Pada Tabel 2 solusi Neighborhood tersebut ditransformasi menjadi solusi Neighborhood VRP (PerhatikanTabel 5).

Tabel 5 Solusi Neigborhood VRP.

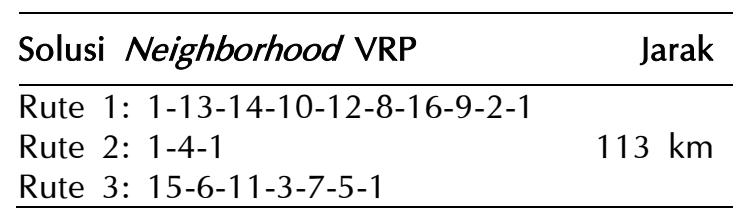

3. Langkah selanjutnya yaitu memilih solusi terbaik di antara solusi Neighborhood yang telah diperoleh pada langkah sebelumnya. Solusi Terbaik adalah solusi dengan jarak terpendek.

4. Setelah diperoleh solusi terbaik pada langkah sebelumnya maka node yang telah digunakan dimasukkan ke dalam Tabu List sehingga tidak akan digunakan pada iterasi selanjutnya.

5. Proses Algoritma Tabu Search diulang kembali mulai dari langkah 2 dan akan berhenti ketika kriteria pemberhentian terpenuhi. Diperoleh Solusi optimal menggunakan algoritma Tabu Search kemudian direpresentasikan pada peta Yogyakarta dan sekitarnya.

Tabel 6 Solusi Optimal VRP.

\begin{tabular}{cllr}
\hline Rute & Solusi VRP & Permintaan & Jarak \\
\hline 1 & $1-10-12-8-16-2-9-14-13-1$ & 240 liter & $29 \mathrm{~km}$ \\
2 & $1-4-1$ & 300 liter & $9,2 \mathrm{~km}$ \\
3 & $1-15-6-11-3-5-7-1$ & 240 liter & $62,9 \mathrm{~km}$ \\
\hline \multicolumn{2}{c}{ Total jarak tempuh kendaraan } & $101,1 \mathrm{~km}$ \\
\hline
\end{tabular}

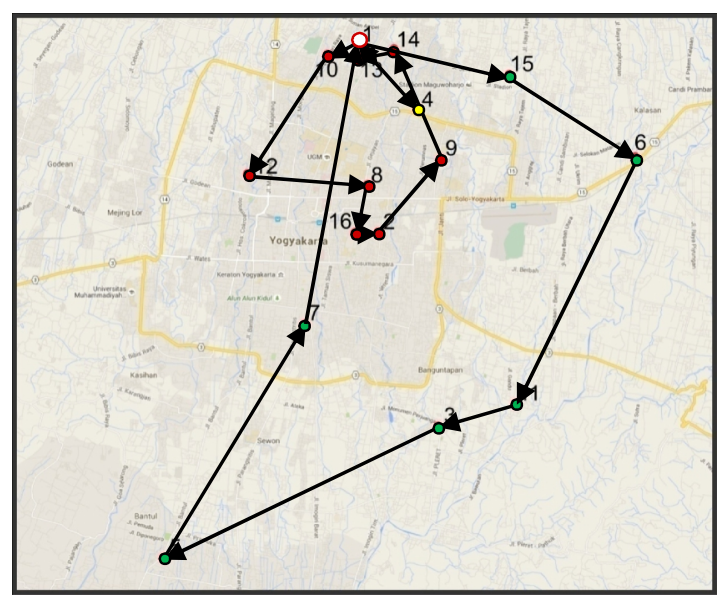

Gambar 1 Solusi optimal pendistribusian Bioseptik. 


\section{Rancang Bangun Algoritma Tabu Search dalam Menyelesaikan VRP}

Rancang bangun Algoritma Tabu Search dalam menentukan rute terpendek pada pendistribusian produk Bioseptik dalam bentuk program menggunakan Matlab 8.1 (R2013a). Program dibuat menggunakan Prosessor Intel' Core" i3 CPU M330 @2,13GHz dan RAM 1024 MB.

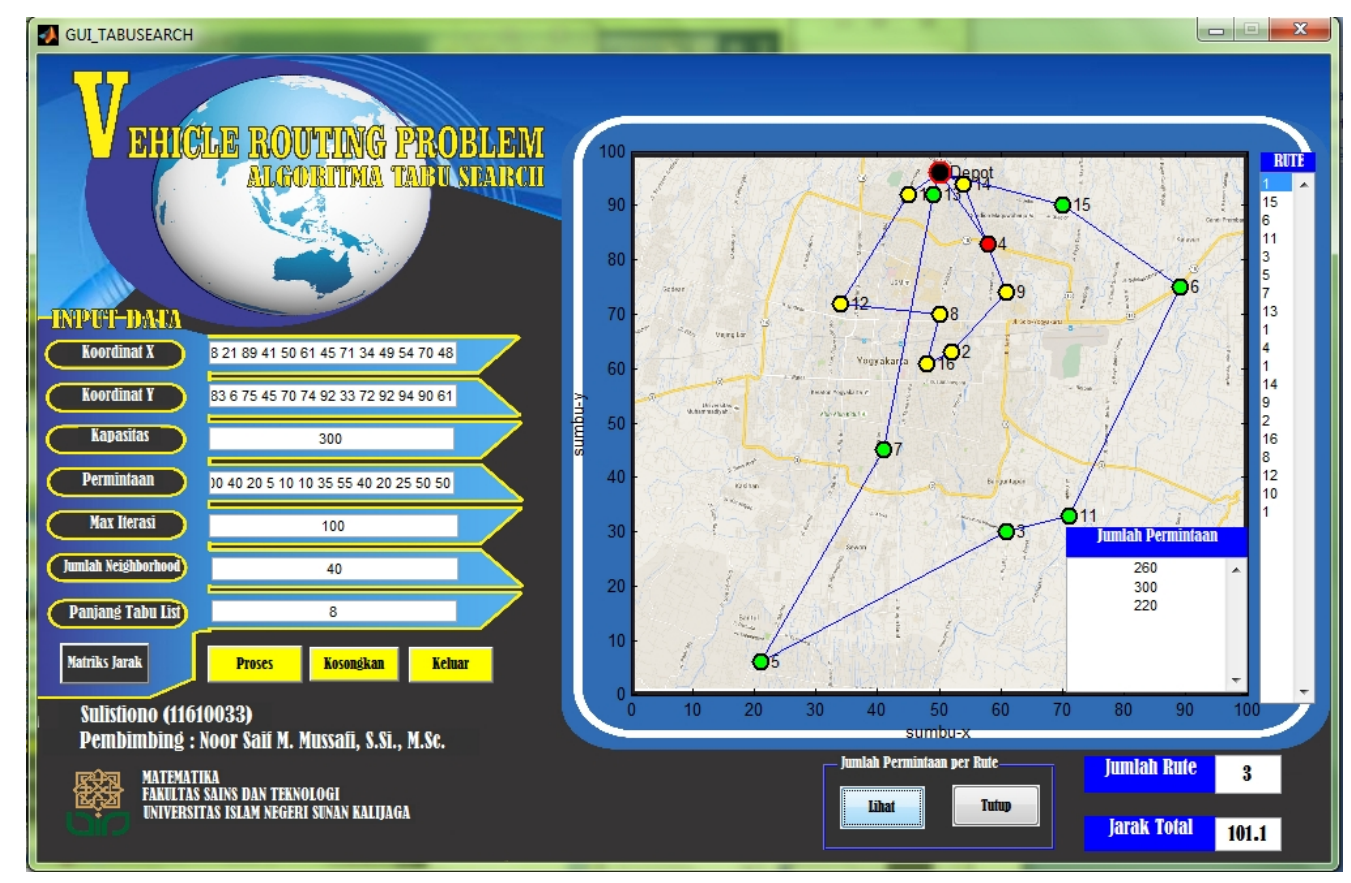

Gambar 2 Program VRP menggunakan Algoritma Tabu Search.

Diperoleh solusi optimal menggunakan program (rancang bangun) pada Gambar 2 sebagai berikut (Perhatikan Tabel 7):

Tabel 7 Solusi Optimal VRP Menggunakan Program.

\begin{tabular}{clcr}
\hline Rute & Solusi VRP & Permintaan & Jarak \\
\hline 1 & $1-15-6-11-3-5-7-13-1$ & 260 liter & $63,8 \mathrm{~km}$ \\
2 & $1-4-1$ & 300 liter & $9,2 \mathrm{~km}$ \\
3 & $1-14-9-2-16-8-12-10-1$ & 220 liter & $28,1 \mathrm{~km}$ \\
\hline \multicolumn{2}{r}{ Total jarak tempuh kendaraan } & $101,1 \mathrm{~km}$ \\
\hline
\end{tabular}

Jarak solusi optimal tersebut sama dengan solusi optimal menggunakan perhitungan manual yaitu sebesar $101,1 \mathrm{~km}$ tetapi memiliki rute kunjungan yang berbeda.

\section{Kesimpulan}

Berdasarkan hasil pembahasan tentang penerapan Algoritma Tabu Search pada Vehicle Routing Problem dapat ditarik kesimpulan sebagai berikut:

1. Proses perhitungan Algoritma Tabu Search terdiri dari lima langkah. Langkah pertama yaitu menentukan solusi awal sebagai iterasi 0 dan menetapkan nilai solusi awal sebagai nilai solusi optimum sementara. Langkah kedua yaitu mencari solusi Neighborhood (solusi alternatif) yang tidak melanggar tabu atau memenuhi kriteria aspirasi. Langkah ketiga yaitu memilih solusi terbaik diantara solusi Neighborhood pada tiap iterasi yang akan disimpan sebagai solusi optimum. Langkah keempat yaitu memperbarui Tabu List dengan memasukkan node yang telah digunakan pada pertukaran node di langkah ketiga. Langkah terakhir yaitu apabila kriteria pemberhentian dipenuhi maka proses 
perhitungan Algoritma Tabu Search berhenti dan diperoleh solusi optimum, jika tidak dipenuhi maka proses kembali berulang dimulai pada langkah kedua.

2. Program (rancang bangun) dibuat menggunakan MATLAB yang dimulai dengan membuat source code utama menggunakan m.file sebagai kode untuk menjalankan program dan kemudian desain tampilan untuk program dirancang menggunakan fig-file sehingga diperoleh program dalam bentuk GUI (Graphical User Interface) pada MATLAB.

3. Pada kasus PT Sinergi Bio Natural diperoleh solusi optimum dengan menggunakan Algoritma Tabu Search. Jarak terpendek yang didapat menggunakan perhitungan manual dan rancang bangun adalah $101,1 \mathrm{~km}$. Berdasarkan hasil perhitungan dihasilkan dua solusi rute perjalanan optimum alternatif menggunakan perhitungan manual dan rancang bangun sebagai berikut (lihat Tabel 8.):

Tabel 8 Solusi optimum perhitungan manual dan rancang bangun.

\begin{tabular}{cllll}
\hline \multirow{2}{*}{ Rute } & Manual & & \multicolumn{2}{l}{ Rancang Bangun } \\
\cline { 2 - 5 } & Solusi Optimum & Permintaan & Solusi Optimum & Permintaan \\
\hline 1 & $1-10-12-8-16-2-9-14-13-1$ & 240 liter & $1-15-6-11-3-5-7-13-1$ & 260 liter \\
2 & $1-4-1$ & 300 liter & $1-4-1$ & 300 liter \\
3 & $1-15-6-11-3-5-7-1$ & 240 liter & $1-14-9-2-16-8-12-10-1$ & 220 liter \\
\hline
\end{tabular}

\section{Referensi}

[1] Alkallak, I. S \& Shaban, R. Z. (2008). Tabu Search Method For Solving The Traveling Salesman Problem. Raf. J. of Comp. \& Maths. 5:141-153

[2] Balakrishnan, R. \& Ranganathan, K. (2012). A Textbook of Graph Theory Second Edition.New York: Springer.

[3] Caric, Tonci \& Gold, Hrvoje. (2008). Vehicle routing problem. University of Zagreb: In-teh Croatia.

[4] Etiner, Selim. (2003). An Iterative Hub Location and Routing Problem for Postal Delivery Sysems.Turki: The Middle East Technical University.

[5] Christopher, Martin. (2011). Logistics \& Supply Chain Management Fourth Edition.United Stated of America: Prentice Hall, Inc.

[6] Cordeau, J.F., Laporte, G., Savelsbergh, M.W., et al. (2007). Vehicle Routing. Handbook on OR \& MS.14: 367370.

[7] Gendreau, M. (2002). An Introduction to Tabu Search. University of Montreal: Montreal

[8] Glover, F \& Kochenberger, G.A. (Eds). (2003). Handbook of Metaheuristics. Dordrecht: Kluwer Academic Publisher.

[9] Glover, F \& Laguna, M. (1997). Tabu Search. Massachusetts: Kluwer Academic Publisher.

[10] Glover, F \& Marti, R. (2006). Metaheuristic Produres for Training Neural Networks. Alba and Marti (Eds.), Springer: 53-70.

[11] Gooddairrie, Edgar G. \& Parmenter, Michael M. (2002). Discrete Mathematics with Graph Theory Second Edition. United States of America: Prentice-Hall, Inc.

[12] Kallehauge, B., Larsen J., \& Marsen OBG. (2001). Lagrangean Duality Applied on Vehicle Routing Problem with Time Windows. Technical Report. IMM. Technical University of Denmark. DK-2800 Kgs. Lyngby Denmark Knight, Andrew. (2000). Basic of MATLAB and Beyond. Boca Raton: CRC Press LLC.

[13] Kusumadewi, S \& Purnomo, H. (2005). Penyelesaian Masalah Optimasi dengan Teknik-Teknik Heuristik. Graha Ilmu.

[14] Mahendra, Berlian T \& Wahyuningsih, Sapti. (2013). Analisis Kerja Algoritma Tabu Search pada Vehicle Routing Problem with Backhaul (VRPB) dengan Perbaikan 2-Opt.Malang: FMIPA Universitas Negeri Malang.

[15] Mailto US. (10 Juni 2011). TSP for VRP Solution with Capacity Constraint Using Tabu Search Algoritm. Diambil pada tanggal 28 Juli 2015, dari http://www.en.pudn.com.

[16] Mutakhiroh, Ling., Saptono, Fajar. , Hasanah, Nur., Wiryadinata, Romi. (2007). Pemanfaatan Metode Heuristik Dalam Pencarian Jalur Terpendek Dengan Algoritma Semut Dan Genetika, Yogyakarta, Seminar Nasional Aplikasi Teknologi Informasi.

[17] Nugroho, Dwi Satio. (2015). Penerapan Algoritma Reverse Delete dalam Menentukan Minimum Spanning Tree Obyek Wisata Di Kota Yogyakarta. Skripsi, tidak diterbitkan, Universitas Islam Negeri Sunan Kalijaga: Yogyakarta.

[18] Nurhayanti, S. (2013). Perbandingan Metode Branch and Bound dengan Metode Clarke and Wright Savings untuk Penyelesaian Masalah Distribusi Aqua Galon di PT.Tirta Investama Yogyakarta. Skripsi, tidak diterbitkan, Universitas Negeri Yogyakarta: Yogyakarta.

[19] Pavela, Vylda \& Nurhadi, Imam. (2012). Penyelesaian Vehicle Routing Problem dengan Menggunakan Algoritma Nearest Neighbor dan Tabu Search (Studi Kasus di PT Nippon Indosari Corpindo). Matematika.1: 1-9.

[20] Pradhana, Fajar Eska. (2011). Penerapan Algoritma Tabu Search untuk Menyelesaikan Vehicle Routing Problem. Skripsi, tidak diterbitkan, Universitas Negeri Semarang: Semarang.

[21] Raditya, Aji. (2009). Penggunaan Metode Heuristik dalam Permasalahan Vehicle Routing Problem dan Implementasinya di PT Nippon Indosari Corpindo.Skripsi, tidak diterbitkan, Institut Pertanian Bogor: Jawa Barat. 
[22] Rahmat, Basuki. 2011. Perbandingan Genetic Algorithm, Multiple Ant Colony System, dan Tabu Search untuk Penyelesaian Vehicle Routing Problem With Time Windows(VRPTW).Jawa Timur.

[23] Rosen, Kenneth H. 2012. Discrete Mathematics and Its Application Seventh Edition.NewYork: Mc-Graw-Hill.

[24] Sugiharto, Aris. 2006. Pemrograman GUI dengan MATLAB. Yogyakarta: Penerbit Andi.

[25] Suyanto. 2010. Algoritma Optimasi Deterministik atau Probabilitik.Yogyakarta: Grahallmu.

[26] Solomon, M \& Desrosiers, J. 1988. Time window constrained routing and scheduling Problems. Transportation science, vol. 22

[27] Taha, H. A. 2003. Operations Research: An Introduction seventh Edition. Prentice Hall, Inc.

[28] Toth, P \& Vigo, D. 2002. The Vehicle Routing Problem. Philadelphia: Siam.

[29] Viktaria, Anie. 2015. Efektivitas Algoritma Simulated Annealing dan Large Neighborhood Search dalam Penyelesaian Pickup and Delivery Vehicle Routing Problem with Time Windows. Skripsi, tidak diterbitkan, Universitas Negeri Yogyakarta: Yogyakarta. 